\title{
Research on the Computer Multimedia Aided Technology effect on CBE Teaching System \\ Xiangbin Gao
}

Linyi University, Shandong 273400, China

gxb0715@126.com

Keywords: CBE, Computer-aided technology

\begin{abstract}
Computer Based Education (CBE) is an important research field in the informational era. CBE research has developed greatly by the research work and persist efforts for many years. CBE theory is the core of educational theory. It emphasizes the students' professional ability. Compared with the rapid development of computer network technology, the teaching content and arrangement of computer network curriculum usually lag behind. A computer network curriculum teaching mode based on CBE is proposed. The students' learning enthusiasm is inspired. Students' professional ability and practical ability are enhanced.
\end{abstract}

\section{Introduction}

1.1 The introduction of CBE

CBE is the ability based education. In the World War II, it is a training mode for technical staff in the United States. By the middle of twentieth Century, it is widely used in vocational education teacher training. After the spread to Canada, it gradually extended to Europe, Asia, Australia and many other countries and regions in the late twentieth Century ${ }^{[1]}$. In China, research on the computer aided education is entering a new stage of multi-plane and multi-subject participation. It brought to a revolution in the field of education. It causes the whole educational concept, teaching environment, teaching method, teaching organization form, teaching means, the relationship between the human and the human in education, teaching and learning in all kinds of behavior and so on. It is one kind of vocational education thought. Competency based curriculum model is relative to the subject based thinking. Its center is the emphasis on the cultivation of students' ability in curriculum development and curriculum design in the core position, rather than blindly emphasize the role of the knowledge system. In this mode, the evaluation of students depends on the ability of the students to engage in some kind of occupation, rather than the degree of professional knowledge.

\subsection{The contents of $\mathrm{CBE}$}

From the beginning of the early program teaching, with the passage of time and technology development, the CBE research on object and the research content are continuous develop. CBE study on computer application in the field of education, it composed two important branch fields: CAI (Computer Assisted Instruction) and CMI (Computer Management Instruction).

CAI is to use the computer help or replace the teacher to performance some teaching tasks, impart knowledge to students and provide skills training. It serves for students. The research contents include: the core technology of CAI, such as courseware development technology, network technology, multimedia technology and artificial intelligence technology. Teaching model and strategy, such as teaching mode of teaching, inquiry teaching mode, problem based teaching model, collaborative teaching model and so on. Teaching method included: considering the effectiveness of human computer teaching from the perspective of teachers and teaching effectiveness from the perspective of teaching software production staff.

CMI is a variety of application of computer in school management. It included two aspects. One part is CMEA. It consists of file management, educational administration management, school resource management, financial management, personnel management and so on. Another is computer assisted instruction management. It composed of CAT, teaching monitoring system, CIPS 
and data base and its management.

$\mathrm{CBE}$ is a new cross discipline. It supports by computer software and hardware technology, network communications, chip technology and other technologies. At the same time, it also need such as pedagogy, psychology, brain science, social science and other blend the subject's theory as a guide. The orientation of CBE research is to research on the application of computer in the field of education and teaching, the elements and their relationships in a computer - based information technology. It promotes study.

\section{The Implementation of the CBE Mode}

The implementation of the CBE mode includes 6 parts. It is shown as figure $1^{[2]}$. There are as follows:

(1) In CBE education mode, teachers are required to familiar with every aspect of implement CBE features. And they need pay attention to training student's personal qualities and know accurately evaluated the students basic vocational skills. And the teachers should to give students advice and encouragement. So the teachers will transform from the disseminators of knowledge to learning process of managers.

(2) Compared with the traditional mode of education, CBE education mode has the characteristics of the school learning content to meet the needs of the actual market related industries. So it is easily to set up learning plan and implement a scientific and specific educational learning program.

(3) In CBE mode, the practice of organization and teaching in the classroom is focused on the basis of each student's knowledge. Classroom provides students with more learning materials, which will guide our daily classroom teaching content.

(4) CBE education model is based on market research and social prediction to determine the professional and job skills analysis. It based on job skills to determine the students to learn the knowledge and skills.

(5) CBE model requires students to be in good condition is very important. Teachers should introduce $\mathrm{CBE}$ overview and the study plan of the operating system, learning system, guidance system in CBE mode to students. They should make students achieve the goal and know the importance of the CBE mode.

(6) The role of teachers in the CBE model is to provide guidance and evaluation. In the management of daily teaching affairs, teachers must provide students with a wealth of learning resources and ensure the normal learning progress of students. 


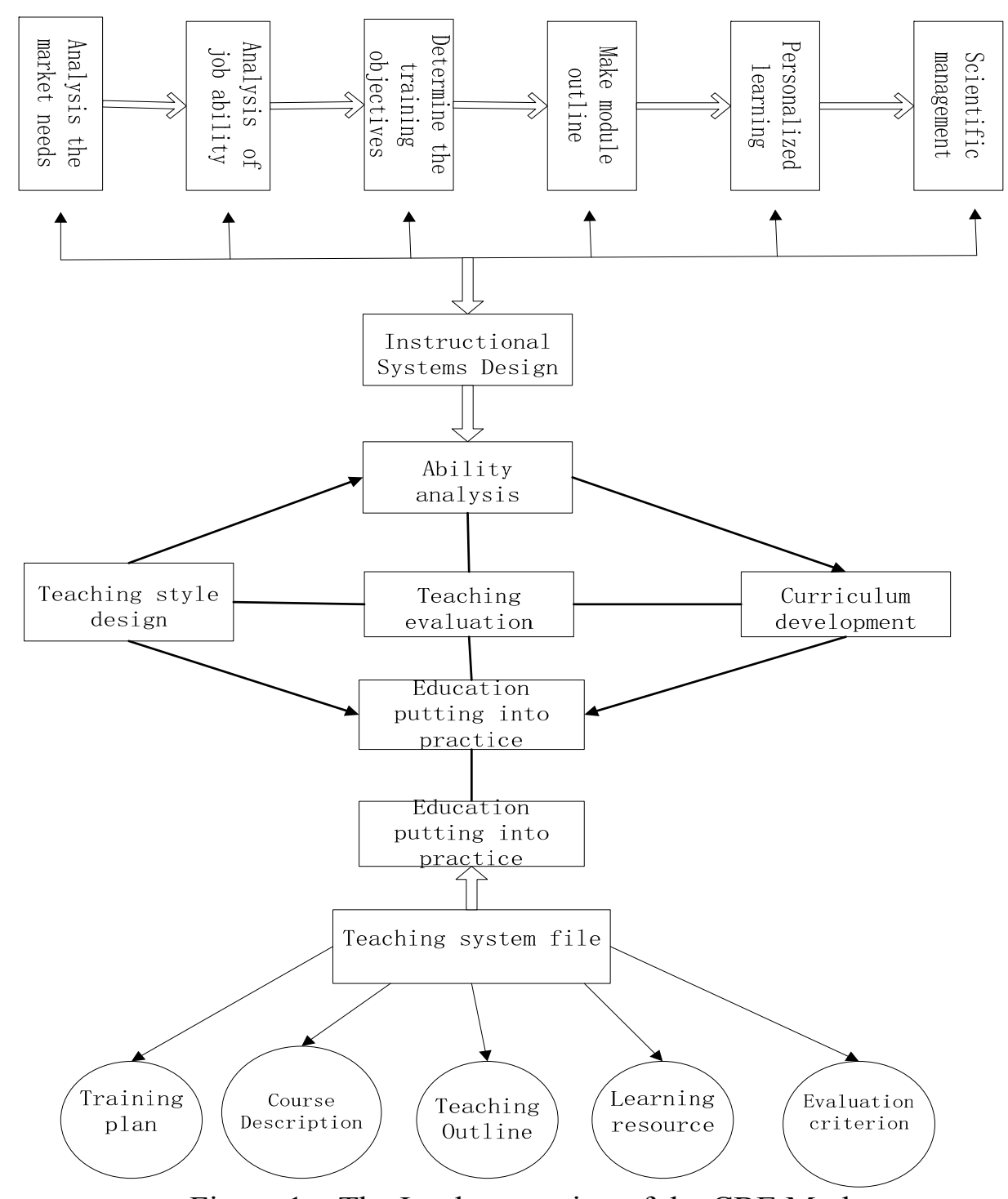

Figure 1 The Implementation of the CBE Mode

\section{The Advantage of CBE applied in the Computer Multimedia Aided Technology}

The computer network teaching system based on CBE is the application of CBE thought to the teaching of computer network. It pays attention to training students' practical ability of computer network knowledge. The computer network knowledge, students' ability, the relevant curriculum design and teaching methods are unified in such a system. The computer network knowledge, the related curriculum design and the teaching method service for the student ability, lack of any one of them may not be able to achieve the final results. Computer network talents which trained by such a system, it need to meet the specific needs of the talent market for career. And to cultivate practical talents as the independent college, this teaching system is undoubtedly the best choice.

Compared with the traditional teaching system, CBE mode of computer network teaching system has the following characteristics:

(1) Breaking the subject - oriented teaching mode, the establishment of the ability - based computer network teaching model. It develops students ' independent learning.

(2) The aim is to improve the ability of computer network related professional ability directly. $\mathrm{Be}$ able to grasp the direction of learning, which is a great help for students to enter the community.

(3) The goal is clearer, and the ability to develop is the main purpose of teaching. Give full play to the initiative of students in the curriculum implementation. Content of the course can not only come from the content of the scientific world, but must take the actual life as the background and the source.

(4) It is flexibility. Students can make self - learning and self - assessment according to their 
own characteristics. Teachers can also be diversified teaching and management according to the purpose of teaching.

\section{Conclusion}

According to CBE teaching mode, computer network course can be divided into several special abilities. It can develop the students' learning skills related to the program, and then combined with the corresponding theoretical teaching, so that students learn through a variety of skills to improve their practical ability. CBE teaching in the study provides a large number of close to the life and scientific knowledge. It is conducive to stimulate students' interest in learning, mobilize the students' subjectivity. So as to better realize the students to create courses. CBE teaching model provides learning opportunities and conditions for students. And through the self evaluation and teacher's review to determine a student's ability, which is to cultivate students the responsibility view.

CBE teaching mode is a kind of teaching mode which is mainly based on the cultivation of students' ability. It is distinguished from the traditional mode of the subject. In promoting quality education, the teaching reform of students' practical ability is emphasized. Using CBE teaching mode can fully tap the potential of the students, and to make it better and faster to adapt to the society and the workplace.

\section{References:}

[1] Huang Yuanming. The Discussion of the CBE Research[J]. Research on higher education of Journal of Guangxi Economic Management Cadre College, 2006,06.

[2] Zhang Haitao. CBE Model in Vocational Exploration and Research in Mathematics Teaching[J]. Soochow University, 2011,09.

[3] Betty .L. Stout . CBE is a way of removing Extemporaneous thinking and Unrelated object [D]Texas Tech University JVHEE, Volume 4, Number 2, Fall 1986.

[4] SA Engum, J Pamela, F Lisa. Intravenous Catheter training System: Computer-based Education versus Traditional learning Methods[J]. American Journal of Surgery, 2003, 186(1):67-74.

[5] FJ Garćia-Peñalvo, LV Safont. Human Behaviors in Computer-based Education Systems[J]. Computers in Human Behavior, 2014, 31:432-433.

[6] M Crehange. An Intelligent Image-based Computer-aided Education System: The Prptotype Birds, Springer New York, 2014:228. 